\title{
ENDOSCOPIC CHARACTERISTICS OF PATIENTS WITH COMPLETE PATHOLOGICAL RESPONSE AFTER NEOADJUVANT CHEMOTHERAPY FOR GASTRIC AND ESOPHAGOGASTRIC JUNCTION ADENOCARCINOMAS
}

\author{
CARACTERÍSTICAS ENDOSCÓPICAS DE PACIENTES COM RESPOSTA PATOLÓGICA COMPLETA APÓS \\ QUIMIOTERAPIA NEOADJUVANTE PARA ADENOCARCINOMAS GÁSTRICOS E DE JUNÇÃO ESOFAGOGÁSTRICA
}

Juliana Silveira Lima de CASTRO ${ }^{1 \oplus}$, Adriane Graicer PELOSOF $^{1 \oplus}{ }^{\circ}$, João Guilherme Guerra de ANDRADE-CABRAL ${ }^{1 \oplus}$, Alvaro Moura SERAPHIM ${ }^{1 \oplus}$, Eloy TAGLIERI ${ }^{1 \oplus}$, Felipe Jose Fernandez COIMBRA $^{2 \oplus}{ }^{\circ}$, Claudia ZITRON $^{1 \oplus}$

\begin{abstract}
BACKGROUND: Gastric and esophagogastric junction adenocarcinoma are responsible for approximately $13.5 \%$ of cancer-related deaths. Given the fact that these tumors are not typically detected until they are already in the advanced stages, neoadjuvancy plays a fundamental role in improving long-term survival. Identification of those with complete pathological response (pCR) after neoadjuvant chemotherapy (NAC) is a major challenge, with effects on organ preservation, extent of resection, and additional surgery. There is little or no information in the literature about which endoscopic signs should be evaluated after NAC, or even when such re-evaluation should occur. Aim: To describe the endoscopic aspects of patients with gastric and esophagogastric junction adenocarcinomas who underwent NAC and achieved $\mathrm{pCR}$, and to determine the accuracy of esophagogastroduodenoscopy (EGD) in predicting the PCR. METHODS: A survey was conducted of the medical records of patients with these tumors who were submitted to gastrectomy after NAC, with anatomopathological result of PCR. RESULTS: Twenty-nine patients were identified who achieved pCR after NAC within the study period. Endoscopic responses were used to classify patients into two groups: G1-endoscopic findings consistent with pCR and G2-endoscopic findings not consistent with pCR. Endoscopic evaluation in G1 was present in an equal percentage (47.4\%; $p=0.28)$ in Borrmann classification II and III. In this group, the predominance was in the gastric body $(57.9 \% ; p=0.14)$, intestinal subtype with $42.1 \%$ $(p=0.75)$, undifferentiated degree, 62.5\% $(p=0.78)$, Herb + in $73.3 \%(p=0.68)$. The most significant finding, however, was that the time interval between NAC and EGD was longer for G1 than G2 (24.4 vs. 10.2 days, $p=0.008$ ). CONCLUSION: EGD after NAC seems to be a useful tool for predicting $p C R$ and it may be possible to use it to create a reliable response classification. In addition, the time interval between NAC and EGD appears to significantly influence the predictive power of endoscopy for pCR. HEADINGS: Neoadjuvant therapy. Stomach neoplasms. Treatment outcome. Endoscopy, digestive system. Neoplasm staging
\end{abstract}

RESUMO - RACIONAL: O adenocarcinoma gástrico e da junção esofagogástrica é responsável por aproximadamente $13,5 \%$ das mortes relacionadas ao câncer. Dado que esses tumores não são normalmente detectados até que já estejam em estágios avançados, a neoadjuvância desempenha um papel fundamental na melhoria da sobrevida em longo prazo. A identificação daqueles com resposta patológica completa ( $\mathrm{PCR}$ ) após a quimioterapia neoadjuvante (NAC) é um grande desafio, com efeitos na preservação do órgão, extensão da ressecção e cirurgia adicional. Há pouca ou nenhuma informação na literatura sobre quais sinais endoscópicos devem ser avaliados após a NAC, ou mesmo quando essa reavaliação deve ocorrer. OBJETIVO: Descrever os aspectos endoscópicos de pacientes com adenocarcinoma gástrico e da junção esofagogástrica que foram submetidos à quimioterapia neoadjuvante e alcançaram pCR, e determinar a acurácia da esofagogastroduodenoscopia (EGD) em predizer a $\mathrm{pCR}$. MÉTODOS: Foram revisados os prontuários de pacientes submetidos à gastrectomia subtotal e total após NAC, com resultado anatomopatológico de pCR. RESULTADOS: Vinte e nove pacientes que alcançaram pCR após NAC foram identificados no período estudado. As respostas endoscópicas foram usadas para classificar os pacientes em dois grupos: G1- achados endoscópicos consistentes com pCR, G2 - achados endoscópicos não consistentes com pCR. A avaliação endoscópica no $\mathrm{G} 1$ esteve presente em igual percentual $(47,4 \% ; p=0,28)$ na classificação de Borrmann II e III. Nesse grupo, a predominância foi no corpo gástrico $(57,9 \% ; p=0,14)$, subtipo intestinal com $42,1 \%(p=0,75)$, grau indiferenciado, 62,5\% ( $p=0,78)$, Herb + em 73,3\% ( $p=0,68)$. O achado mais significativo, no entanto, foi que o intervalo de tempo entre NAC e EGD foi maior para G1 do que G2 (24,4 vs. 10,2 dias, $p=0,008)$. CONCLUSÃO: A EGD após NAC, nessa pesquisa, sugeriu ser método útil para prever $\mathrm{PCR}$, mediante uma classificação de resposta confiável. Além disso, o intervalo de tempo entre NAC e EGD parece influenciar significativamente a sua capacidade preditiva de diagnosticar a pCR.

DESCRITORES: Terapia neoadjuvante. Neoplasias gástricas. Resultado do tratamento. Endoscopia do sistema digestório. Estadiamento de neoplasias.

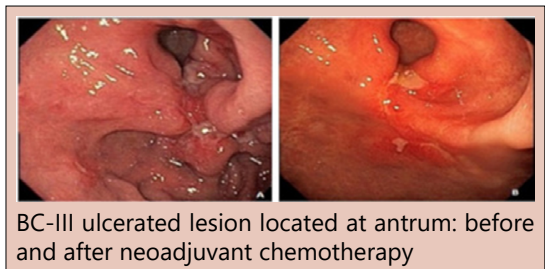

\section{Central message}

Esophagogastroduodenoscopy after neoadjuvant chemotherapy for gastric and esophagogastric junction adenocarcinomas can be a useful tool for tumor staging and selection of surgical candidates.

Perspective
This is the first study to describe the endoscopic
features after neoadjuvant chemotherapy
for gastric and esophagogastric junction
adenocarcinomas and the ideal time interval
between neoadjuvant chemotherapy and
surgery. The identification of patients with
complete pathological response after
neoadjuvant chemotherapy could, in the future,
become a tool to select those who really benefit
from adjuvant chemotherapy and perhaps
suppression of surgery for patients at high risk
for the procedure.

From the ${ }^{1}$ A.C. Camargo Cancer Center, Endoscopy Unit, São Paulo, SP, Brazil; ${ }^{2}$ A.C. Camargo Cancer Center, Gastrointestinal Surgical Oncology Unit, São Paulo, SP, Brazil

How to cite this article: Castro JSL, Pelosof AG, Andrade-Cabral JGG, Seraphim AM, Taglieri E, Coimbra FJF, Zitron C. Arq Bras Cir Dig.2021(3):e1616. https://doi. org/10.1590/0102-672020210002e1616

Correspondence:

Juliana Silveira Lima de Castro

Email: julianasilveira_@hotmail.com
Fundings: None

Conflict of interest: None

Received: 19/07/2021

Acepted: 04/09/2021 
D espite a reduction in the incidence of gastric adenocarcinoma (GC) in the last decade, it remains the third most common cause of cancer-related death in the world, with an estimated 783,000 deaths per year ${ }^{5}$.The incidence of adenocarcinoma of the esophagogastric junction (GEJ) has increased markedly in Western countries in recent years ${ }^{5,4}$. Population analyses in the United States have reported an almost 2.5-fold increase in incidence since the $1970 s^{14}$. In Brazil, GC is the $5^{\text {th }}$ most common cancer overall $\left(3^{\text {th }}\right.$ among men and $5^{\text {th }}$ among women) ${ }^{15}$. For each year from 2020 to 2022 it has been projected that there will be 13,360 new cases in men and 7,870 new cases in women per hundred thousand people ${ }^{15}$. For esophageal adenocarcinoma in Brazil, there are expected to be 8,690 new cases in men and 2,700 new cases in women per hundred thousand ${ }^{15}$. GC development can be induced by the interactions of multiple genetic and environmental factors in complex ways ${ }^{23}$.

Currently, the recommended therapeutic approach for locally advanced tumors of the stomach and GEJ is perioperative chemotherapy ${ }^{3,7}$. Several studies have demonstrated this strategy to yield increased rates of complete resection, downstaging, overall survival, and progression-free survival ${ }^{3,8}$. It has also been noted that some tumors exhibit better responsiveness than others ${ }^{7,8}$. Therefore, diagnostic methods that can predict a complete pathological response ( $p C R$ ) have important clinical implications ${ }^{7,22}$. Several combined chemotherapy regimens have shown good efficacy for GC and non-resectable GEJ allowing a potential curative gastrectomy ${ }^{22}$. Among these regimens, the most used today is the FLOT scheme, composed of fluorouracil, leucovorin, oxaliplatin, and docetaxel ${ }^{2}$ In patients with locally advanced lesion above clinical stage tumor (cT) 2 or compromised lymph nodes, neoadjuvant chemotherapy (NAC) can increase the likelihood of curative surgery, with complete tumor response rates around $10 \%$ and increased rates of both progression-free and overall survival ${ }^{9,21}$. In addition, NAC can offer treatment options for patients for whom surgery is risky, such as those with more advanced disease progression ${ }^{4}$. The identification of patients with $\mathrm{pCR}$ after NAC could, in the future, become a tool to select those who really benefit from adjuvant chemotherapy and perhaps even in the suppression of surgery to patients at high risk for the procedure, becoming a useful tool in the decision multidisciplinary therapy ${ }^{4}$. In general, the morbidity rate of radical gastrectomies is around $33.5 \%$ and mortality between $0.6 \%$ to $4.7 \%{ }^{11,16}$. According to a 2015 study the overall survival of stage III/IV patients who underwent NAC and who obtained PCR was similar to those with stage I/II who did not receive NAC 6 . Recently published data demonstrated that pathological staging was better than conventional staging at predicting responsiveness to and survival after neoadjuvancy ${ }^{7}$. Other studies have also indicated that location in GEJ and TNM are associated with a worse prognosis ${ }^{8}$. Preoperative endoscopic evaluation of patients undergoing NAC is recommended in many services, but as of the writing of this paper there has been no published description of endoscopic findings in these patients and the ideal time interval between NAC and surgery remains unclear.

Therefore, in the present study we investigated the following questions: 1) What are the endoscopic features that support detection of pCR following NAC? 2) What is the diagnostic accuracy and sensitivity of esophagogastroduodenoscopy (EGD) in the assessment of pCR following NAC? and 3) What time interval between NAC and EGD supports optimal response prediction?
This is a retrospective study in a single center specializing in cancer treatment. The medical records were revised of patients with GC and GEJ type adenocarcinoma who were submitted to gastrectomy after NAC with an anatomopathological result of $\mathrm{pCR}$.

From October 2010 to September 2018, we identified 31 patients aged $\geq 18$ years who underwent total or subtotal gastrectomy after NAC for the treatment of CG and GEJ and who exhibited pCR. All patients were treated at A.C. Camargo Cancer Center, São Paulo, SP, Brazil. Clinical stages of patients ranged from cT2-cT4. Were excluded two patients that missed the examinations. The study was approved by the ethics and research committee of A.C. Camargo Cancer Center, under number: 2892/20.

\section{Study design}

All EGDs were performed by two senior endoscopists using 150 and 180 videoendoscopies (Olympus Medical System Corporation, Hachioji-shi, Tokyo, Japan).

\section{Esophagogastroduodenoscopy 1 (EGD1)}

PatientsunderwentEGD with biopsy and anatomopathological studies that confirmed GC or GEJ adenocarcinomas. At this time the macroscopic aspect of the lesion was classified according to Borrmann classification (BC) as: BC-I, well-defined polypoid or vegetating lesion; $\mathrm{BC}-\mathrm{II}$, ulcerated lesion, well-delimited with clear edges; $\mathrm{BC}$-III, ulcerated lesion, infiltrative in part or all of its borders; BC-IV, diffusely infiltrative lesion, with no limit between the tumor and the normal mucosa.

After the histopathological diagnosis patients were staged using a computed tomography (CT) scan of the chest, abdomen, and/or pelvis and fluoro-2-deoxyglucose positron emission tomography/computed tomography (FDG-PET/CT).

Patients underwent NAC with a scheme based on fluoracil and platinum, with either 8 or 12 cycles, half of the sessions being performed before surgery and the remainder in the postoperative period.

\section{Esophagogastroduodenoscopy 2 (EGD2)}

Within 30 days of the end of preoperative NAC, all patients again underwent EGD and were reclassified according to the macroscopic aspect of the lesion. After NAC, patients underwent partial or total gastrectomy with D2 lymphadenectomy and surgical specimens were processed according to standard procedures.

The histopathological studies of surgical specimens were performed using the World Health Organization's classification scheme for neoplasms of the digestive system as well as Lauren's classification, with the following characteristics recorded: subtype, Lauren type, depth of invasion in the wall, lymph node status, vascular and neural infiltration ${ }^{19}$.

All surgical specimens were analyzed by two independent pathologists using the tumor regression score as recommended by the National Comprehensive Cancer Network ${ }^{1}$. According to this scale, a score of zero indicates complete response and comprises no viable cancer cells, including in lymph nodes. All of the 29 patients included in this study showed scores of zero and complete anatomopathological responses.

\section{Objectives and definitions}

The primary objectives of this study were to describe the endoscopic aspects of patients with gastric or GEJ adenocarcinomas submitted to NAC who exhibited $\mathrm{pCR}$, and to determine the accuracy of EGD in predicting this response in these patients.

A complete endoscopic response (eCR) was determined by the presence of an endoscopic scar (reddish or whitish) 
without active lesions after NAC (Figure 1A/B). Patients who met this criterion were included in group $1(G 1, n=19)$. Patients who exhibited active lesions (ulcers) after NAC were included in group $2(G 2, n=10$; Figure $2 A / B)$.

Secondary objectives of this study were to evaluate whether factors such as gender, age, tumor location, BC, cT, lymph node status, histopathological subtype, degree of differentiation, Herb2 marker status, and time interval between NAC and EGD2 may influence the sensitivity of EGD to predict $\mathrm{PCR}$.

\section{Statistical analysis}

All statistical analyses were performed using IBM SPSS software version 25 . Statistical significance was set as $p<0.05$. Absolute ( $n$ ) and relative (\%) frequency distributions were evaluated for qualitative variables, and main summary measures (mean, standard deviation, median, minimum, maximum) for quantitative variables. Chi-square and Fisher's exact tests were used to determine the association between qualitative variables and the presence of scarring. The Mann-Whitney non-parametric test was used to associate quantitative variables with the presence of scar. If an association was found between scar and any variable, logistic regression was used to calculate the odds ratio. For evaluation of the scar in relation to $\mathrm{PCR}$, the main diagnostic measures (sensitivity, specificity and accuracy) were calculated.

\section{RESULTS}

Characteristics of patients and tumors are summarized in Table 1. Although there were more males enrolled than females, genders were distributed similarly across groups $(p=0.22)$.

The $\mathrm{G} 1$ group compared to $\mathrm{G} 2$ group, more patients presented with GC $(73.7 \%, p=0.67)$ CT $3(68.4 \%, p=0.72)$, and
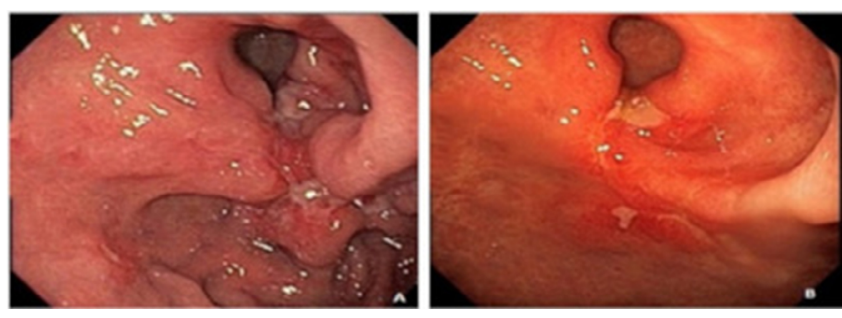

Figure 1 - Group 1: A) Esophagogastroduodenoscopy preneoadjuvant chemotherapy showing Borrmann classification-III ulcerated lesion located in cardia; B) esophagogastroduodenoscopy post- neoadjuvant chemotherapy showing scar.
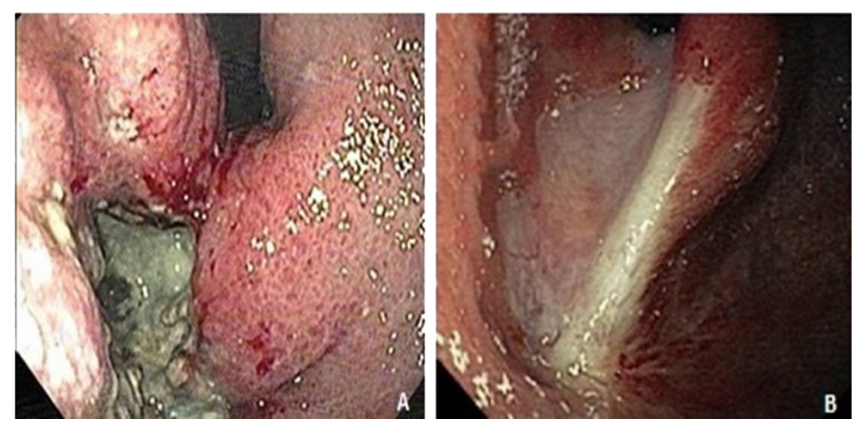

Figure 2 - Group 2: A) Esophagogastroduodenoscopy preneoadjuvant chemotherapy showing Borrmann classification-III ulcerated lesion located at antrum; B) esophagogastroduodenoscopy post-neoadjuvant chemotherapy showing active lesion
Table 1 - Characteristics of patients and tumors

\begin{tabular}{lcccc|} 
Variable & \multicolumn{2}{c}{ G1 } & \multicolumn{2}{c}{ G2 } \\
\cline { 2 - 5 } & $\mathbf{n}$ & $\%$ & $\mathbf{n}$ & $\%$ \\
Age (years) & 58.3 & - & 65.1 & - \\
Gender & & & & \\
$\quad$ Male & 14 & 73,6 & 8 & 80 \\
$\quad$ Female & 5 & 26,3 & 2 & 20 \\
Siewert Classification & & & & \\
$\quad$ II & 5 & 26.3 & 4 & 40 \\
III & 14 & 73.7 & 6 & 60
\end{tabular}

\section{Localization}

$\begin{array}{lcccc}\text { Cardia } & 5 & 26.3 & 4 & 40 \\ \text { Body } & 11 & 57.9 & 2 & 20 \\ \text { Antrum } & 3 & 15.7 & 4 & 40\end{array}$

\section{Grade}

$\begin{array}{lllll}\text { Poorly differentiated } & 10 & 52.6 & 7 & 70\end{array}$

$\begin{array}{lllll}\text { Moderately differentiated } & 5 & 26.3 & 2 & 20\end{array}$

$\begin{array}{lllll}\text { Well differentiated } & 1 & 5.2 & 0 & 0\end{array}$

Unknown

$\begin{array}{llll}3 & 15.7 & 1 & 10\end{array}$

\section{Signet ring cell histology}

$\begin{array}{lcccc}\text { Absent } & 9 & 47.3 & 5 & 50 \\ \text { Present } & 10 & 52.6 & 5 & 50\end{array}$

$\begin{array}{ccccc}\text { cT category } & 0 & 0 & 0 & 0 \\ 1 & 3 & 15.7 & 3 & 30 \\ 2 & 13 & 68.4 & 6 & 60 \\ 3 & 3 & 15.7 & 1 & 10 \\ 4 & & & \end{array}$

$\begin{array}{lcccc}\text { cN status } & 13 & 68.4 & 9 & 90 \\ \text { Negative } & 6 & 31.5 & 1 & 10 \\ \text { Positive } & 0 & 0 & 0 & 0 \\ \text { CM category } & \end{array}$

$\begin{array}{lcccc}\text { Endoscopic findings before chemotherapy } & \\ \text { BC-I } & 0 & 0 & 0 & 0 \\ \text { BC-II } & 9 & 47.3 & 2 & 20 \\ \text { BC-III } & 9 & 47.3 & 8 & 80 \\ \text { BC-IV } & 1 & 5.2 & 0 & 0\end{array}$

\section{cHerb}

$\begin{array}{lcccc}\text { Positive } & 2 & 10.5 & 3 & 30 \\ \text { Negative } & 11 & 57.8 & 5 & 50 \\ \quad \text { Unknown } & 2 & 10.5 & 1 & 10 \\ \text { Histological type } & & & & \\ \quad \text { Diffuse } & 7 & 36.8 & 4 & 40 \\ \text { Intestinal } & 8 & 42.1 & 2 & 20 \\ \quad \text { Mixed } & 4 & 21 & 2 & 20 \\ \text { Type of resection } & 10 & 52.6 & 2 & 20 \\ \quad \text { Total gastrectomy } & 9 & 47.3 & 8 & 80 \\ \quad \text { Subtotal gastrectomy } & & & & \\ \text { Lymph node dissection } & 0 & 0 & 0 & 0 \\ \text { D1 } & 19 & 100 & 10 & 100 \\ \text { D1+/D2 } & \end{array}$

Endoscopic findings during or after chemotherapy

$\begin{array}{lcccc}\text { Scar } & 19 & 100 & 0 & 0 \\ \text { Lesion } & 0 & 0 & 10 & 100\end{array}$

$\mathrm{cT}=$ clinical stage tumor; $\mathrm{cN}=$ clinical stage lymph nodes; $\mathrm{cM}=$ clinical stage metastasis; $\mathrm{BC}=$ Borrmann classification 
absent lymph node status ( $68.4 \%, p=0.59)$. After $E G D$, the lesions were classified in equal proportions as BC-II and BC-III $(47.4 \%$, $\mathrm{p}=0.28)$, more in the gastric body $(57.9 \%, p=0.14)$ and the histopathological study showed that, the intestinal subtype was present in $42.1 \%$ (p: 0.75), undifferentiated degree, $62.5 \%$ $(p=0.78)$, Herb + in $73.3 \%(p=0.68)$.

The time interval between the last NAC cycle and the realization of the reevaluation by EGD was higher in $\mathrm{G} 1$ compared to G2. In G1 this average was 24.4 days [minimum: 5 days; maximum: 61 days, standard deviation (SD): 16] and in G2 the mean was 10.2 (minimum: 2, maximum: 5, SD: 10.4), (p: 0.008), odds ratio (OR) 1.12 and [confidence interval $(\mathrm{Cl}): 1.0-1.2$ ]. mean 24.4 days (5-61), standard deviation (SD): 16] and 10.2 (minimum: 2, maximum: 5, SD: 10.4$)$ respectively (p: 0.008), odds ratio (OR) 1.12 and [confidence interval $(\mathrm{Cl}): 1.0-1.2]$

The ideal time calculated for performing EGD after NAC was 8.5 days. At this time, a sensitivity of $93 \%$ and specificity was reached: $66 \%$ (CI: 0.6-1.0). EGD after NAC showed accuracy in predicting endoscopic complete response (eCR) and sensitivity, $\mathrm{G} 1$, in $65.5 \%$ of the analyzed cases. All cases underwent surgical treatment with partial gastrectomy, total gastrectomy with or without distal esophagectomy associated with D2 lymphadenectomy, with a finding of $p C R$ in the surgical specimen in an average of 43.8 days in both groups, with the average in $\mathrm{G} 1$ being 52 , and in G2 39 days after endoscopic control.

\section{DISCUSSION}

GC is one of the most common neoplasms in the world, with high rates of incidence and mortality ${ }^{20}$. The most common location is the gastric antrum although the incidence of GEJ tumors is gradually increasing ${ }^{13}$. GEJ tumors are very prevalent worldwide and are among the most aggressive tumors of the digestive tract ${ }^{5}$. Furthermore, in most western countries they are not diagnosed until the more advanced stages, when isolated surgical treatment is less effective ${ }^{6}$. The low rate of early gastric cancer is related to the lack of specific symptoms ${ }^{19}$. Advanced tumors exhibit considerable metastatic potential and generally worse prognosis, indicating a need for combined systemic and local treatments to reduce the risk of tumor recurrence ${ }^{12}$

Complementary treatments associated to radical surgery are being more frequently indicated and have demonstrated significant efficacy ${ }^{2,7,19}$.

For advanced cancers, the most successful treatments are combined chemotherapy with surgery ${ }^{2,6,20}$. However, there are few tools to restaging patients before the surgical procedure ${ }^{10}$.

This study describe the pre-operative endoscopic findings of 29 patients with GC and GEJ cancer who were submitted to NAC and who achieved pCR after surgery. Methods for assessing tumor response and metastases after chemotherapy include endoscopic ultrasound, CT, and PET-CT, but these techniques show low accuracy and the possibility of over or under-staging ${ }^{17,18}$.

The study included EGD performed by two independent senior endoscopists, after the neoadjuvant treatment. The exams were performed within 30 days of the end of NAC, and surgery was performed 4-8 weeks after the end of NAC.

The EGD was able to predict pCR in $65.5 \%$ of cases (G1). In addition, the time interval between the end of NAC and the performance of EGD2 was significantly shorter for the group in which EGD was unable to predict pCR (G2) and for each additional day there was a $12 \%$ increase in the probability of predicting $\mathrm{PCR}$.

The ideal time calculated to perform EGD was 8.5 days after ending NAC, at which point sensitivity reached $93 \%$.
The presence of active lesions in G2 may have been due to inflammatory responses that occur during normal healing of the mucosa. In these cases, EGD performed later may have revealed scarring compatible with that observed in $\mathrm{G} 1$.

\section{CONCLUSION}

The eCR, determined by the presence of endoscopic scar, reddish or whitish, without active lesions after NAC, was consistent with the pCR. EGD after NAC showed accuracy in predicting $\mathrm{eCR}$ and sensitivity in $65.5 \%$ of the cases analyzed. The minimum time interval for performing EGD after the end of NAC was 8.5 days. Respecting this interval may increase the possibility of predicting $\mathrm{PCR}$ with endoscopic evaluation and supports optimal response prediction

\section{REFERENCES}

1. Bray F, Ferlay J, Soerjomataram I, Siegel RL, Torre LA, Jemal A. Global cancer statistics 2018: GLOBOCAN estimates of incidence and mortality world wide for 36 cancers in 185 countries. CA Cancer J Clin. 2018;68:394-424. DOI: 10.3322/caac.21492

2. LinD, KhanU, GoetzeTO, ReizineN, Goodman KA, Shah MA, Catenacci VD, Al-BatranSE, PoseyJA. Gastroesophagealjunctionadenocarcinoma: is there an optimal management? Am Soc Clin Oncol Educ Book. 2019;39:e88-e95. DOI: 10.1200/EDBK_236827

3. Ministério da Saúde. Instituto Nacional de Câncer. Estimativa 2020. incidência de Câncer no Brasil. Rio de Janeiro: INCA; 2019.

4. Zare $\mathrm{M}$, Jafari-Nedooshan J, Aghili $\mathrm{K}$, Ahrar $\mathrm{H}$, Jarahzadeh $\mathrm{MH}$, Seifi-Shalamzari N, Zare-Shehneh M, Neamatzadeh H. Association of MMP-7 -181a>g polymorphism with colorectal cancer and gastric cancer susceptibility: a systematic review and metaanalysis. Arq Bras Cir Dig. 2019;32(3):e1449. doi: 10.1590/0102$672020190001 \mathrm{e} 1449$

5. Coimbra FJF, de Jesus VHF, Ribeiro HSC, Diniz AL, de Godoy AL, de Farias IC, Felismino T, Mello CAL, Almeida MF, Begnami MDFS et al. Impact of ypT, ypN, and adjuvant therapy on survival in gastric cancer patients treated with perioperative chemotherapy and radical surgery. Ann Surg Oncol. 2019;26:3618-26. DOI: 10.1245/ s10434-019-07454-0

6. Barchi LC, Ramos MFKP, Dias AR, Forones NM, Carvalho MP, Castro OAP, Kassab P, Costa-Júnior WLD, Weston AC, Zilberstein $B$ et al. Brazilian Gastric Cancer Association guidelines (part 2): update on treatment. Arq Bras Cir Dig. 2021;34(1):e1563. doi: 10.1590/0102-672020210001e1563.

7. Felismino TC, de Oliveira ACF, Alves ACF, da Costa Junior WL, Coimbra FJF, de Souza Begnami MDF, Riechelmann RP, Jesus VHF, Mello CAL. Primary tumor location is a predictor of poor prognosis in patients with locally advanced esophagogastric cancer treated with perioperative chemotherapy. J Gastrointest Cancer. 2020;51:484-90. DOI: 10.1007/s12029-019-00258-1

8. Tada K, Etoh T, Shitomi Y, Ueda Y, Tojigamori M, Shiroshita $H$, Shiraishi N, Inomata M. A case of advanced gastric cancer achieved a pathological complete response by chemotherapy. Surg Case Rep. 2017;3:68. DOI: 10.1186/s40792-017-0344-9

9. Al-Batran SE, Homann N, Pauligk C, Goetze TO, Meiler J, Kasper S, Kopp HG, Mayer F, Haag GM, Lindig U et al. Perioperative chemotherapy with fluorouracil plus leucovorin, oxaliplatin, and docetaxel versus fluorouracil or capecitabine plus cisplatin and epirubicin for locally advanced, resectable gastric or gastrooesophageal junction adenocarcinoma (FLOT4): a randomised phase 2/3 trial. Lancet. 2019;393:1948-57. DOI: 10.1016/S01406736(18)32557-1 
10. Ikoma N, Blum M, Estrella JS, Das P, Hofstetter WL, Fournier KF, Mansfield P, Ajani JA, Badgwell BD. Evaluation of the American Joint Committee on Cancer 8th edition staging system for gastric cancer patients after preoperative therapy. Gastric Cancer. 2018;21:74-83. DOI: 10.1007/s10120-017-0743-4

11. Stark AP, Ikoma N, Chiang YJ, Estrella JS, Das P, Minsky BD, Blum MM, Ajani JA, Mansfield P, Badgwell BD. Characteristics and survival of gastric cancer patients with pathologic complete response to preoperative therapy. Ann Surg Oncol. 2019;26:360210. DOI: $10.1245 / \mathrm{s} 10434-019-07638-8$

12. Bartlett EK, Roses RE, Kelz RR, Drebin JA, Fraker DL, Karakousis GC. Morbidity and mortality after total gastrectomy for gastric malignancy using the American College of Surgeons National Surgical Quality Improvement Program database. Surgery. 2014;156:298304. DOI: 10.1016/j.surg.2014.03.022

13. Jung MR, Park YK, Seon JW, Kim KY, Cheong O, Ryu SY. Definition and classification of complications of gastrectomy for gastric cancer based on the accordion severity grading system. World $J$ Surg. 2012;36:2400-11. DOI: 10.1007/s00268-012-1693-y

14. Papenfuss WA, Kukar M, Oxenberg J, Attwood K, Nurkin S, Malhotra U, Wilkinson NW. Morbidity and mortality associated with gastrectomy for gastric cancer. Ann Surg Oncol. 2014;21:3008-14. DOI: $10.1245 / \mathrm{s} 10434-014-3664-z$

15. Cho H, Nakamura J, Asaumi Y, Yabusaki H, Sakon M, Takasu $N$ Kobayashi T, Aoki T, Shiraishi O, Kishimoto H, Nunobe $\mathrm{S}$, et al. Long-term survival outcomes of advanced gastric cancer patients who achieved a pathological complete response with neoadjuvant chemotherapy: a systematic review of the literature. Ann Surg Oncol. 2015;22:787-92. DOI: 10.1245/s10434-014-4084-9

16. Smyth EC, Verheij M, Allum W, Cunningham D, Cervantes A, Arnold D. Gastric cancer: ESMO Clinical Practice Guidelines for diagnosis, treatment and follow-up. Ann Oncol. 2016;27(suppl 5):v38-v49. DOI: 10.1093/annonc/mdw350

17. Ajani JA, D'Amico TA, Almhanna K, Bentrem DJ, Chao J, Das $P$, Denlinger CS, Fanta P, Farjah F, Fuchs CS, et al. Gastric Cancer, Version 3.2016, NCCN Clinical Practice Guidelines in Oncology.J Natl ComprCancNetw.2016;14:1286-12. DOI: 10.6004/jnccn.2016.0137

18. Song Z, Wu Y, Yang J, Yang D, Fang X. Progress in the treatment of advanced gastric cancer. Tumour Biol.2017;39:1010428317714626. DOI: 10.1177/1010428317714626

19. Li B, Liu HY, Guo SH, Sun P, Gong FM, Jia BQ. Detection of microsatellite instability in gastric cancer and dysplasia tissues. Int J Clin Exp Med. 2015;8:21442-7. PMID: 26885089

20. Kurokawa $Y$, Shibata $T$, Sasako $M$, Sano T, Tsuburaya A, Iwasaki $Y$, Fukuda $\mathrm{H}$. Validity of response assessment criteria in neoadjuvant chemotherapy for gastric cancer (JCOG0507-A). Gastric Cancer. 2014:17:514-21. DOI: 10.1007/s10120-013-0294-2

21. Japanese Gastric Cancer Association. Japanese classification of gastric carcinoma--2nd English edition--response assessment of chemotherapy and radiotherapy for gastric carcinoma: clinical criteria. Gastric Cancer. 2001;4:1-8. DOI: 10.1007/s101200100009

22. Park SR, Lee JS, Kim CG, Kim HK, Kook MC, Kim YW, Ryu KW, Lee $\mathrm{JH}$, Bae JM, Choi IJ. Endoscopic ultrasound and computed tomographyin restaging and predicting prognosis afterneoadjuvant chemotherapy in patients with locally advanced gastric cancer. Cancer. 2008;112:2368-76. DOI: 10.1002/cncr.23483

23. Redondo-Cerezo E, Martínez-Cara JG, Jiménez-Rosales R, ValverdeLópez F, Caballero-Mateos A, Puente J P, Fernández JLA, Muñoz MU, Hierro ML, Teresa J. Endoscopic ultrasound in gastric cancer staging before and after neoadjuvant chemotherapy. a comparison with PET-CT in a clinical series. United European Gastroenterol J. 2017;5:641-7. DOI: 10.1177/2050640616684697 